\title{
THE PORTRAYAL OF JOURNALISTS IN TURKISH CINEMA: A STUDY ABOUT JOURNALISM ETHICS THROUGH CINEMA
}

Hasan Gürkan

IZVORNI ZNANSTVENI RAD / DOI: 10.20901/ms.8.16.4 / PRIMLJENO: 04.04.2017.

ABSTRACT This study discusses journalism and how well this profession is framed according to the professional codes of journalism. It focuses on Turkish films made between 1980 and 1990. In the early 1980s, journalism became an important issue with the coercion of the mass media under the Turkish Republic. Gazeteci (The Journalist), Rahmet ve Gazap (Rahmet and Gazap), and Uyanık Gazeteci (The Vigilant Journalist) are the films based on the profession of journalism made during this era. The selected films discuss the freedom of the press, expression, and media ethics, and these themes are intertwined with the melodramatic element of 'love'. In the films, many dialogues show that the duty of the press is aiding justice or that a journalist must always defend press freedom and write the truth. Social obedience throughout the history of the Turkish Republic is also emphasised in these films.

KEY WORDS

PORTRAYAL OF JOURNALISM, ETHICS IN FILMS, CINEMA IN TURKEY, THE 1980s, MASS MEDIA

Author Note

Hasan Gürkan :: Istanbul Arel University, School of Communication, Radio-Television and Cinema, Turkey :: gur.hasan@gmail.com 


\section{INTRODUCTION}

Cinema can change people's attitudes, behaviours, and thoughts; the public is influenced by cinema, and cinema itself can create trends. Thus, cinema is not only a medium that carries the portrayal of power, but it is also is a medium that allows people with opposing views to express their thoughts. Cinema has three basic functions economic, ideological, and aesthetic - that determine the structures of mainstream and alternative cinema. As Michel Foucault (2015) points out, there is a parallel link between politics and mass media in the power struggle. Every power must legitimise its own presence. While power tries to legitimise its own presence with the mass media, it also intends that its politics are supported by public opinion. Political authorities or those in power use the mass media in order to explain significant issues to the public and for changing minds.

In this sense, the present study focuses on how the profession of journalism is represented in cinema in Turkey. There are a limited number of studies on the representation of journalists in films. These studies are written by Sarah Niblock (2007), Matthew Ehrlich (2004; 2006a; 2006b), and Alexa Milan (2010). However, these three Turkish films - The Journalist (1980, dir. Yücel Uçanoğlu), Rahmet and Gazap (1980, dir. Mesut Uçakan), The Vigilant Journalist (1988, dir. Kartal Tibet) - have no similarities with other films analysed in the mentioned research. Niblock (2007), Ehrlich (2004; 2006a; 2006b) and Milan (2010) particularly contain different themes, such as journalists in media, work-life balance, working conditions, the woman's role in the newsroom, unethical behaviour, the representation of good journalists and bad journalists, current media issues, nostalgia in media, and the free media myth. On the other hand, the selected three films in this study state the more basic issues of journalism, such as the freedom of expression, freedom of the press, and media ethics. In international films that deal with journalism, the audience is often involved in characters' private lives. In these Turkish films the audience witnesses only the main problems of the journalists. For instance, even though gender issues and discrimination are still a problem in Turkey, they are not mentioned in these films. Besides these issues mentioned above the only study about the representation of journalists in cinema in Turkey is Amca Size Gazeteci Diyebilir Miyim? (Uncle, Can I Call You Journalist?) by Mehmet Sağnak (2010). In his book, Sağnak (2010) discusses the portrayal of journalism as a profession in films. He also states that Turkish films based on journalism are filmed within the desired media atmosphere.

In the history of cinema in Turkey, there are also few films whose main characters are journalists, the first of which is the film entitled Cici Berber (The Pretty Barber, 1933, dir. Muhsin Ertuğrul and Nazım Hikmet). This film is known as the first Turkish film with a journalist as a leading character. In areas concerning civil disobedience and the press in cinema in Turkey, the titular character, Vatandaş Rıza (Citizen Rıza, 1979, dir. Cüneyt Arkın), goes on a hunger strike in Taksim Square in Istanbul in Turkey. In Oyunbozan (Doublecrosser, 2000, dir. Nesli Çölgeçen), Kemal, one of the leading characters is a poet/columnist. The most memorable film based on journalists in recent history is Basın (Press, 2011), which was written and directed by Sedat Yilmaz. The film follows a group of journalists 
in Diyarbakır during the early 1990s when Turkey was one of the leading countries with the greatest number of journalists killed. In this sense, it is possible to state that cinema in Turkey points out what is on the agenda in Turkey, such as victim journalists, or regaining the freedom of news gathering and writing.

A study of the cinematic history in Turkey shows that few films focus on the topic of journalism. Additionally, the majority of these films date back to the 1980s and 1990s. This seems to go parallel with the political and social history of Turkey and is directly related to the new social and political structure constructed by the military coup on September 12,1980 . In this sense, in the early 1980 s, journalism became a major issue with the mass media under pressure of the military coup and subsequent government leaders in the Turkish Republic.

\section{MEDIA ETHICS IN TURKEY}

Media ethics refers to gaining and maintaining public trust. In other words, media ethics means the precaution taken by media professionals. Media ethics covers the principles and the rules, which are considered by journalists in news writing and reporting. These principles and rules are related to how the journalists act.

Nelson Crawford (1924), Leon Nelson Flint (1925), William Futhey Gibbons (1926), and Albert Henning (1932) have discussed ethical issues in the field of media since the beginning of the $20^{\text {th }}$ century. The issues addressed within the framework of media ethics are categorised into three different groups: professional, economic, and social-cultural. Accuracy in the news, distortion in the news, manipulation in the news, canard, and respect for private life, defamation and slander in the news, and censorship in the news all fall into the group of professional issues and matters. Monopolies in media and concerns of circulation appear among the economic issues and matters. Gender issues can be categorised among social-cultural matters (Thayer, 1973, 1980; Heine, 1975; Meyer, 1983; Schmuhl, 1984; Jensen, 1997; Patterson and Wilkins, 1998).

It is an economical issue that should be explained through monopolies. Media owners write news to increase their circulation rates by ignoring the ethical principles and rules. This news, covering topics like violence, sexism, and private lives, are then released to the public. Philip Meyer (1987), Conrad Fink (1995), Jeffrey Olen (1988), Hazel Dicken-Garcia (1989), and Kaarle Nordenstreng and HIfzI Topuz (1989) studied ethics in media and underlined the manipulation in the news as another issue. This refers to interfering with the content of news. There are two kinds of manipulation: interfering with journalists and interfering with media organisations. This is especially seen among media conglomerates and within the monopolisation process. Manipulation in the news is done through journalistic techniques, such as altering stories, and using different images. News manipulation is done by creating a dramatic headline instead of giving a standard one before reporting the related news. The aim of such manipulative news is to direct the readers' perception (Meyer, 1987; Fink, 1995; Olen, 1988; Dicken-Garcia, 1989; Nordenstreng and Topuz, 1989). 
Journalists have the right to relay information to the public, but at the same time, they are required not to exceed the limits of acceptable criticism and to relay the information to the public without defamation and slander. Hence, journalists' commentary must be constrained in the news. Moreover, the journalist does not have the right to make derogatory or abusive comments (Juusela, 1991; Patterson and Wilkins, 1998; Besley and Chadwick, 1992; Demir, 2006).

Another commonly discussed issue is the respect for the private life. Journalists write news by protecting the public interest. When the public interest is discussed, the general opinion is towards revealing private life and privacy. On the other hand, there are unspoken rules that prohibit disrespecting anyone's private life and privacy (Ibid.).

Censorship in the news is one of the most important issues regarding media ethics. Censorship is one of the biggest obstacles facing the press and it is often applied in two ways, as close censorship and open censorship. Close censorship covers the process before the news is issued. As the editors or chief editors decide to issue the news, they censor its content news. Open censorship covers the process after the news has been issued. This kind of censorship is exercised to put down the problems. While open censorship is applied by the government and supervisory boards, close censorship is applied by editors, chief editors and media owners (Gordon and Merrill, 1998; Kieran, 1997).

Social-cultural issues regarding media ethics are based on gender and sex. Sexism in the media is generally related to the representation of women in the media. The media uses women as consumers as well as objects (Hurst and White, 1994; Lester and DanreRoss, 1996). Women's images in part determine the perspective of how men regard women (Bıçakçı, 2001). According to these scholars, another social-cultural issue is sexuality in the media. The reactions of audiences devoted to sexuality in the media change depending on the age, sex, social status and personal characteristics of audiences. In Turkey, sexuality in the media refers to the images and the scenes with female and male nudity (Demir, 2006).

To sum up, basic principles of media ethics can be discussed as a conglomeration in the media sector creates problems for journalism. Media organisations cannot release the news about the actions of the organisation it belongs to (Dominick, 2004). The economy plays an important role in the media sector and media organisations gain profit in thanks to their circulation.

Media ethics are based on the liberal paradigm found in the contemporary world. The Marxist (Critical) paradigm, which opposes the liberal paradigm, rejects media ethics. Hasan Gürkan and Başak Gezmen (2016) discuss the principles of these two paradigms regarding journalists, news, and media organisations. According to the liberal paradigm, a journalist is objective and reflects the truths (Gürkan and Gezmen, 2016: 23-25). The Professional Journalism Ideology ${ }^{1}$ is based on the objectivity of journalists, news, and

\footnotetext{
${ }^{1}$ The Professional Journalism Ideology is based on objectivity, social responsibility, professionalism, and the relation between news and acicularity since the second half of the 1800s. James Curran states that this ideology is the result of capitalization of media sector through the 19th century. The defects of media can be hidden with this ideology (Gürkan and Gezmen, 2016).
} 
media organisations. Media organisations are the $4^{\text {th }}$ force ${ }^{2}$ in democratic societies. These organisations counterbalance the relationship between the governing and the governed. The news must be objective and accurate (Ibid.). On the contrary, the critical (Marxist) paradigm says that a journalist is a human, and cannot be objective. She has her own culture and knowledge. Media organisations belong to governing elites and the powerful. Hence, the media is an area that is dominated by the sovereign and the powerful. The news is written by using language, and language can never be objective. Language reconstructs reality and it emphasises that the news is a reconstruction of reality (Ibid.).

In Turkey, the media industry started to change after the 1980s. Media monopolies have been a current issue since the second half of the 1980s. Until 1980, all newspaper company owners were members of a journalist family; however, after 1980 businessmen became the new bosses of the media industry (Adaklı, 2006). In other words, these new media owners began to monopolise the media. The biggest threat from this media monopoly is not only preventing journalists from writing the truth, but also preventing plurality in the media. As a result, journalists were obligated to write their news about the people and the institutions closely related to their bosses both ideological and political view points. Consequently, all the journalists who protect the profits of media owners enable the limitation of the freedom of thought and freedom of expression by destroying the freedom of the press and blocking the public's right to know the truth as the result of media monopolies (Adaklı, 2006; Dağtaş, 2006; Dursun, 2004).

In Turkey, the profession of journalism was undergoing the process characterised by massification and industrialisation when the Democrat Party (Demokrat Parti 19461960) was conservative in terms of politics and diplomacy, but on the other hand, the profession of journalism became integrated with capitalism in economic terms (Taş, 2010: 155). Particularly, multi-party democracy was recovered instead of an authoritarian singleparty rule, which played an important role in the process of structurally altering the press.

With the growing strength of the Democrat Party in the political life in Turkey, the press became more influenced by pro-Democrat Party ideals. The newspapers depended on circulation, and advertising income started to protect political objectivity as a founding principle, which signals a clear break in the political position of the press (Taş, 2010: 156).

The 1980s are the years when it was when the important shift to an oligopolistic media market occurred, in which industrial production dominated a press sector that had been based on craft-like production relations (Adaklı, 2010). It has been argued that marketoriented journalism, at the same time, is more socially prestigious and more advantageous in terms of professional competitiveness, and that professional independence can only be possible by adhering to market rules (Özgen, 2004: 152). In the 1980s, journalism began to be considered a profession that serves not only the claim of effectively ensuring the democratic needs of the community, but also in terms of competition, service, and quality standards among the media companies (Adaklı, 2010).

\footnotetext{
$\overline{2}$ The other three forces are legislation, propulsion, and jurisdiction. After these three forces, media is evaluated as the 4 th force particularly for the democracies.
} 
The $25^{\text {th }}$ and $26^{\text {th }}$ articles of the 1982 Constitution, which went into effect on the 11 November 1982, regulates the freedom of communication, such as freedom of thought and freedom of opinion. In the multi-party era after 1983, a set of legal reforms was regulated. For instance, it was a crime ${ }^{3}$ to publish to distribute newspapers, magazines, brochures, flysheets and show bills, etc. (Ibid.)

\section{BACKGROUND OF THE 1980 MILITARY COUP ERA AND MASS MEDIA IN TURKEY}

In Turkey, the 1980s was an era when everything was formed by the pressure and the prohibition of the military coup; on the other hand, the state power, which was not only prohibitive but also provocative, was active during these years (Gürbilek, 2009). Mehmet Ali Birand (1985), Oral Çalışlar (2006), and Çetin Yetkin (1995) describe the cultural atmosphere in Turkey in the 1980s with two terms. The first is "pressures on the expressions", and the second is the "expressions boom". For these authors, the environment was highly oppressive, and there were prohibitions applied by the state's power. The 1980 military coup ${ }^{4}$ depoliticised the society and institutions in Turkey. Both journalists and press organisations were under pressure. The press moved away from its social functions, and it was a stranger to the public's problems (Çalışlar, 2006; Yetkin, 1995). After the military coup on the 12 September in 1980, the press was faced with new limitations and regulations. Besides trying to regain freedom of thought and freedom of expression, it was really hard to protect the economic interest and independence of the journalists. The changes in the collective bargaining agreement left journalists powerless (Ibid.).

The September 12, 1980 military coup limited the liberties much more than the Turkey's past coups, ${ }^{5}$ as its leader strove for permanence. Thus, it hoped that the masses could be depoliticised. It was accompanied by important changeovers in Turkey. It rescinded the 1961 Constitution, which was more liberal and enabled democratic rights to be used. The new Constitution replaced the 1961 Constitution and was more restrictive.

In the first half of the 1980s, the issues involving yellow journalism, described below, and interference in subjects' private life were discussed. Toward the 1990s, all of the ethical concerns ended in the media. The press ignored its role as the $4^{\text {th }}$ power, and thereby ignoring the troubles in the political and the public sphere it started to work for the political elite.

The relationship between reader and newspaper changed in the 1980s. These years also represent the period in which the Turkish media was becoming influenced by investment groups. Media groups started failing in their fulfilment of the traditional

\footnotetext{
${ }^{3}$ This case is similar to contemporary Turkey. Since the July 15, 2016 coup, placed sanctions have been placed on the press through the declared state of emergency.

${ }^{4}$ The September 12 coup was the military intervention carried out by the Turkish Armed Forces on September 12, 1980. With this intervention, the Prime Minister, Süleyman Demirel, was taken from the government office and the Grand Assembly of Turkey was nullified. This period lasted for about nine years, political parties were invalidated, and the party leaders were kept under surveillance and then sentenced.

${ }^{5}$ Other military coups happened on May 27, 1960 and March 12, 1971.
} 
ideals and notions of journalism as the industry underwent a process of monopolisation. In general, the media was governed by economic interests, and the main purpose was not to inform the public. The press transformed the social and political atmosphere whenever it wanted, and it took advantage of the public's trust by doing so. In this sense, the hope of the "idealist approach" from journalists ended as the press changed. Censorship during the military coup helped foster tabloid (yellow) journalism instead of an environment where reporting accurate news was encouraged (Adaklı, 2006; Dağtaş, 2006).

\section{METHOD}

The present study uses a qualitative content analysis. Content analysis, the method of analysing messages, is a favourite method in mass communication studies (Lombard et al., 2002: 587). Content analysis serves as a scientific approach "(a) to describe trends in communication content and patterns of communication, (b) to test hypotheses of message characteristics, (c) to compare media content to the 'real world,' (d) to assess the image of particular groups in society, and (e) to establish a starting point for studies of media effects" (Stroman and Jones, 1997: 272-273). Content analysis involves the process of a rigorous adherence to established rules and steps in order to be most "objective and systematic" (Lewis et al., 2013), and ensure reliability in the study. Therefore, this study follows Susanna Priest's definition of content analysis as "a means of trying to learn something about people by examining what they write, produce on television, or make movies about" (Priest, 1996: 23). Jana Dundelova and Blahoslav Rozboril (2012: 189) point out the advantages of content analysis as following: "It can provide valuable historical/cultural insights over time through the analysis of texts, and it provides insight into complex models of human thought and language use". Therefore, this paper aims to examine the portrayal of journalism in Turkish films and to present an analysis of the three journalism films made during the 1980s and 1990s.

There are 16 films regarding journalism during the 1980s and 1990s in cinema in Turkey. These films ${ }^{6}$ are shown in the table below.

Table 1. Films regarding Journalism during the 1980 s and 1990s in Turkish Cinema

\begin{tabular}{llll} 
Film's Original Title & Film's English Title & Director & Released Year \\
Gazeteci & The Journalist & Yücel Uçanoğlu & 1980 \\
Rahmet ve Gazap & Rahmet and Gazap & Mesut Uçakan & 1980 \\
Talihli Amele & The Lucky Holdman & Başar Sabuncu & 1980 \\
Çirkinler de Sever & The Ugly Love as well & Sinan Çetin & 1981 \\
Seni Kalbime Gömdüm & I've Buried You in My Heart & Feyzi Tuna & 1982 \\
Aile Kadını & The Family Woman & Kartal Tibet & 1983 \\
ÇarıklıMilyoner & A Millionaire with a Sandal & Kartal Tibet & 1983 \\
\hline
\end{tabular}

$\overline{{ }^{6} \text { The films are arranged chronologically. }}$ 


\begin{tabular}{llll} 
Film's Original Title & Film's English Title & Director & Released Year \\
Damga & The Stamp & Osman Seden & 1984 \\
Alev Gibi & Like the Flame & Ümit Efekan & 1986 \\
Namus Düşmanı & The Enemy of Honour & Zeki Alasya & 1986 \\
Yarın Ağlayacağım & I Will Cry Tomorrow & Halit Refiğ & 1986 \\
On Kadın & The Ten Women & Şerif Gören & 1987 \\
Katırılar & The Muleteers & Şerif Gören & 1987 \\
Sürgün & The Exile & Ayni Kütükoğlu & 1988 \\
Gazeteci Kız & The Journalist Girl & Melih Gürgen & 1988 \\
Uyanık Gazeteci & The Vigilant Journalist & Kartal Tibet & 1988 \\
\hline
\end{tabular}

The goal of this study is to provide a great deal of knowledge surrounding journalism and ethics in film throughout the history of Turkish cinema. Moreover, this study also intends to build on that knowledge by addressing more recent films that have not yet been subjected to much research in Turkey. The selected films for the present study are:

>The Journalist (Gazeteci, 1980, dir. Yücel Uçanoğlu), $>$ Rahmet and Gazap (Rahmet ve Gazap, 1980, dir. Mesut Uçakan), $>$ The Vigilant Journalist (Uyanık Gazeteci, 1988, dir. Kartal Tibet),

These three films are selected for this study because the protagonists are journalists and the theme of these films deals with issue of the media. These three films are either solely about journalism or, journalism plays a major role in the plot in each of them, as mentioned above. The only theme in these films is media ethics and this theme is intertwined with the element of 'love'. In the film studies literature, melodrama is described as an artistic representation. It does not reflect or describe social and psychological realities; it signifies these realities in two ways where the melodrama produces a narrated or represented content, the life of people in society; and it narrates and represents a series of standpoints, i.e., subject positions. According to Geoffrey Nowell-Smith (1997), the melodrama arises from the conjunction of a formal history proper - development of tragedy, realism, etc. - a set of social determinations, which have to do with the rise of the bourgeoisie and a set of psychic determinations that form the family. The concepts of westernisation and modernity, and the melancholy associated with it have continued to capture the imagination of the Turkish public into the $20^{\text {th }}$ century.

Pelin Agocuk (2015) offers some important insight about Turkish melodrama films in Turkish cinema. Popular Turkish melodrama films made between the 1960s and 1970s problematised these concepts in their portrayal of the love stories of the rich and the poor, the urbanite and the villager. These films pointed towards a balance between modernity and traditionalism, the East and the West. In the same way as the American melodrama films, Turkish melodrama films have a dichotomy between active heroes and passive heroines (Agocuk, 2015). For example, the contrast of active/passive is, inevitably, traversed by another contrast, that between masculine and feminine in these three 
Turkish films. In the films, The Journalist or The Vigilant Journalist, female characters also are seen as protagonists. When the central figure is a man, like in the film Rahmet ve Gazap, his masculinity is impaired, but on the other hand, the masculinity is reformed and regained in the other two films as well. In these three films, a happy ending may seem impossible and the audience is well aware of this. With the atmosphere of 1980s Turkey, laying out the problems with the status quo allows these three films reflect the truth. However, on the other hand, these three films can be seen as a contradictory nexus, in which the status quo's reflections to the society's social and psychological situation are brought together, but in which the problem of articulating these reflections is not successfully resolved.

The other 13 Turkish films are not included in this study because their protagonists are not journalists and media issues are not the film's main themes. Just Katırcılar (dir. Zeki Ökten, 1987) and Talihli Amele (dir. Başar Sabuncu, 1980) also deal with journalism from a critical perspective more than the other 11 films - except The Journalist, Rahmet and Gazap, The Vigilant Journalist. However, the journalists in these two films are not the main characters, and they have less influence on the narrative trajectory of the main characters in the films. Therefore, these two films are not included in this study.

Since this article is focused on the dilemma between media and ethics dilemma, this study tries to answer the following research questions:

RQ1: How are the issues of media ethics, the freedom of the press, and the freedom of expression discussed in these films?

RQ2: How are the journalists described in the films? Is there a link with the socialcultural context?

RQ3: According to Robert Stam (2000), if the self-reflexivity of films is a political imperative or responsibility as a solution for an issue by revealing traces of self-esteem in the film production, then do the three films convey this responsibility to the viewer, which is necessary for reflection?

\section{FINDINGS AND DISCUSSION}

In order to understand these films better, it is necessary to discuss their plots. The first film, The Journalist (Gazeteci, 1980, dir. Yücel Uçanoğlu), tells a love story between Kemal, a bully who is a smuggler, and Zeynep, a journalist who defends the truth, gathers, and writes articles about smuggling. Zeynep starts to work with Kemal by going undercover. However, after Zeynep writes her articles and they are published in the newspaper, Kemal's business and his smuggling operations become ruined. Kemal tries to find out who wrote the articles, but on the other hand, the relationship between Kemal and Zeynep turns into one of love. Zeynep does not want to betray Kemal and starts to write the articles with her signature. Thereupon, Kemal becomes angry with Zeynep, but their love leads Kemal to change and he gives up smuggling. He also starts to help Zeynep with her articles. The mafia hears about what is going on, and asserts that Kemal must die. The film ends with Kemal's death. 
The second film, Rahmet and Gazap (Rahmet ve Gazap, 1980, dir. Mesut Uçakan), tells a story about a journalist called Abdullah who always defends the truth and is punished as a result. Abdullah writes the truth in his articles, and his boss, who is his father-in-law, reprimands him. Abdullah and his boss (father-in-law) argue about an article that defends the truth written by Abdullah. On the same night, Abdullah's boss is killed. Everyone thinks that Abdullah killed his boss because of the quarrel between them. Abdullah is punished, and in the meantime, another journalist, Yusuf, tries to help Abdullah. Yusuf gathers important information that could help prove Abdullah's innocence. However, Yusuf gets the information too late to save Abdullah from execution.

The third film, The Vigilant Journalist (Uyanık Gazeteci, 1988, dir. Kartal Tibet), is based on a true story that takes place between the borders of Romania and Bulgaria. The film tells a story about the two villages and their residents who cannot get along with each other. They cannot comprise on a "no man's land," which does not belongs to Romania or Bulgaria. Both villages supply what they eat and what they drink from this land. However, when the profit is discussed, there are tensions for this land between the two villages. After a while, the older people come together and seek a remedy to end these tensions. Almost all young people in the two villages are good at wrestling. The older people make a decision about organising a wrestling competition between the two wrestlers of the two villages. As a consequence, the winner of the competition will be allowed to use the disputed land. A newspaper company offers a position to a journalist who has already been dismissed from his former newspaper company. The journalist who goes to the two villages perceives this competition as a war, making the situation worse. In the meantime, the international media is interested in this case.

In the consideration of the research questions, the themes are discussed as below:

\section{Media ethics, freedom of the press and the freedom of expression}

A free press is accepted as an indicator and an assurance of democracy. The mass media uses its power to lead the public in terms of politics and economics. The press helps determine, not only what readers think about, but also how readers think and react. In this manner, the press brings up specific political themes or issues, either highlighting particular political themes or delivers the political issues, themes and facts to the public.

The mass media points the way for societies, disseminates ideologies, and creates the images of social reality. The mass media, in the liberal-pluralist approach, is a voice of the public and a constraint on political power. In other words, the mass media is a monitor and a composer of the freedom of the press and the freedom of expression in liberal democracies. Therefore, the mass media stands as a guarantor of the democratic system and an entry to citizens into the process. The arguments regarding media and democracy reveal freedom of thoughts and ideas.

In The Journalist (Gazeteci, 1980, dir. Yücel Uçanoğlu), professional and social-cultural issues can be seen in terms of media ethics. The accuracy of information is discussed regarding the professional issue. Zeynep follows the accurate news in the film, and she 
deals with the recital of the facts. Even though she falls in love with a smuggler, she still writes the truth in her articles.

In the film, The Journalist, Zeynep is an idealistic journalist who fights to reveal the truth. She values her career above everything else. She defends press freedom at the same time. She defends the profession journalism in every speech to Kemal. It can be understood with the following words:

The assignment of the press is helping justice. They as the press must start a war against the smugglers. (The Journalist, 00:08:04-00:08:40)

When she speaks to Kemal regarding the articles:

Don't be angry with him/her ${ }^{7}$. S/he interprets the news, and the duty of a journalist is this. Please do not forget that there is freedom of the press in Turkey. If there was not freedom of the press, we would not talk about democracy. We do not have the right to keep down anybody's thoughts. (The Journalist, 00:22:1200:22:58)

Zeynep states a point about press freedom in another speech with Kemal:

The focus of the press changes according to the importance of the person and the case. The press may make the man both a hero and a contemptible. (The Journalist, 00:34:28-00:35:01)

In the film, Rahmet and Gazap (Rahmet ve Gazap, 1980, dir. Mesut Uçakan), ethical issues concerning the media can be seen. The film highlights these issues, particularly the following dialogues between Abdullah and his boss (father-in-law). For example, the conversation below shows how the Turkish media sector is affected by the market conditions, because the dominant groups in the media sector in Turkey cover almost all of the sub-sectors. Media groups - the media conglomerates- not only affect newspaper publishing and news agencies, from book, magazine publishing to advertisement and broadcasting, but also include sectors in banking, finance, automotive, tourism, insurance, health, telecom, cement, and energy. In this regard, having a publishing conglomerate in Turkey opens new doors into doing business with the government (Adaklı, 2010):

The Boss: Fool! Have I not told you that you should not write these kinds of articles many times? OK, I got that you are interested in the poor people, etc. but smuggling issues are not your business. You cannot write what you want. In this organization, 50 people are employed.

Abdullah: How do you want me to keep quiet against these issues?

The Boss: As if you are going to save the world! You must focus on your articles. (Rahmet and Gazap, 00:08:30-00:09:02)

The other development regarding the media sector was an increase in tabloid journalism. This kind of journalism, called yellow journalism, includes plenty of images and less news (Atılgan, 1991: 58). It is forbidden, and engaging in this type of dissent plays an important role for tabloid journalism. In that period in Turkey, Turkish society was

\footnotetext{
${ }^{7}$ There is no gender difference in the Turkish language. Therefore, when Turkish people mention third-person singular, they just use "O". It may address to both a male and a female.
} 
misdirected from reality to artificiality through the press. Informing and briefing, which are the main duties of press, were essentially forbidden, and expressing public opposition, under went a process of tabloidization (Özgen, 2004: 68). In the film, the newspaper tries to be transformed from an independent newspaper to a mass popular newspaper. A magazine journalist is transferred to the newspaper.

Yusuf: What are you talking about? What will a magazine journalist do in this important newspaper? Editor-in-Chief: Please, have a seat! If you think that the newspaper will go on its way as it was, you are getting it wrong! We have to turn it into a mass newspaper to increase our circulation. More tabloid news, a lot of lotteries, a lot of photo-romance...

Yusuf: You are trying to turn this into a street newspaper. This is treachery!

Editor-in-Chief: Please, have a seat! I do not think Yusuf is a decision-maker. (Rahmet and Gazap, 00:43:29-00:44:55)

The dialogues above discuss the tabloidisation of Turkish media. Just because as a result of the liberal policies which allowed for the large capital owners and holdings to enter publishing after the 1980s, some negative developments occurred. Tabloidisation and monopolisation limited the use of the freedoms of journalists. In that period, in order to increase public trust toward the press, the press council was established. This council defends the rights of the public to get the truth based on the keystone of a "democratic system with freedom" (Yılmaz, 2015: 177). The politicisation was reflected in the press before the 1980s, the variety and the numbers of opinion newspapers increased during this period. Opinion and mass journalism before the 1980 s were replaced by tabloid press. After the September 12, 1980 military coup, due to the pressures on the media, newspapers preferred to make tabloid news instead of political news. Thus, both the society and the media became non-political after the military coup. On the other hand, according to Jean Chalaby (1998), article series, sensationalism and chauvinism find their meaning in the news. Article series and interviews are prioritised with remarkable promotions. Large and frequent images are used in the news, and they strike an attitude inspired in national issues such as the Cyprus issue, etc. (Taş, 2010: 158). Therefore, Rahmet and Gazap is a representation of tabloid journalism in media sector in the 1980s in Turkey.

Film The Vigilant Journalist (Uyanık Gazeteci, 1988, dir. Kartal Tibet) has absurd comedic elements. Having ironic elements, the film also repeats the motto, "There is freedom of press in Turkey". This motto represents the status of the press, as mentioned above, in Turkey in the 1980s. The dialogue between the journalist and the little boy in the film characterise the situation in Turkey:

The boy: You are making up below, I am making up above ${ }^{8}$. All of the villagers are talking about what you are writing for the newspaper.

The journalist: Bragging?

The boy: No idea, I heard many of the villagers say so! What does bragging mean?

The journalist: Bragging means a lie.

The boy: Are you a liar?

The journalist: Indeed, I am not! But I am a liar in this sense. (The Vigilant Journalist, 00:40:35-00:42:28)

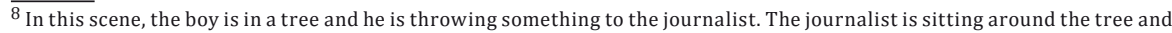
writing his article for the newspaper. The boy means that the journalist fabricates his articles.
} 
At this point, it is significant to mention the press code in the 1980s in Turkey. The press code, composed of with 10 articles, consists of prohibitive provisions and obligations. For instance, issuing an individual opinion and reflecting the truth purposefully are some obligations in news articles. Thus, the differences of editorialisation and fact/worth are reproduced based on an interdictor provision. In this sense, the duties of the journalists are to protect the difference of the reality and advertisement/news in accordance with objectivity seeking, and to observe embargoes from the government against the mass media in order not to abuse freedom (Taş, 2010: 163). The film discusses both the liberal paradigm and the critical (Marxist) paradigm. What the journalist perceives is the tension as the war between the two villages is a reading of the critical paradigm. On the other hand, how the newspaper comments on this case by stating "The war begins" is a reading of the liberal paradigm.

\section{The Portrayal of Journalists}

Cinema plays an important role in shaping stereotypes, especially in the absence of face-to-face interactions with these groups. They help to create and perpetuate national stereotypes. As Srividya Ramasubramanian (2005) states, just like the other forms of mass media, films influence what the audience thinks and how the audience acts against other people. Richard Dyer (1993) says people develop a "schema-stereotype" or a quick shortcut reference for the social group with their 'mental cookies'. Stereotypes can not only be seen as derogatory or close-minded, but they also have a tendency to serve a purpose. Sometimes in society, the use of stereotypes has to be acknowledged as a necessary, indeed inescapable, part of the way societies make sense of themselves, and hence actually make and reproduce themselves.

In these three films, all of the journalists are represented as fair, trustworthy persons, and defenders of truth. This shows that the journalists, as white-collar workers, act against corruption in Turkish society. In that case, it is important to mention Dyer's explanations. When focusing on fictional journalists, stereotypes are used as a mode of characterisation in fiction. The type (the journalist in these films) is any character constructed through the use of a few immediately recognisable and defining traits. Moreover, this means that the journalists' stereotypes are a representation of types; the journalists, Zeynep (in The Journalist), Rahmet and Gazap (in Rahmet and Gazap), and Ali (in The Vigilant Journalist), are the myths of a social type. This allows the audience to easily identify what the journalist character's role is supposed to be in the story. In time, the audience, by using stereotypes, expresses an agreement about this media social group, as if that agreement arose independently of the stereotype. Yet for the most part, it is from the stereotype that the audience gets their ideas about social groups.

Films and other forms of mass media can have similar functions. As discussed above and with the claims of the media cultivation perspective (Gerbner, 1998; Gerbner et al., 2002), how the audiences sees media texts such as films, television films, television series, television programmes and television news on TV and in cinema, after a point, they categorise the stereotypes portrayed on these media as either positive or negative. For this reason, media, such as television and films, which are able to create a realistic 
presentation using their audio and visual features, provide a magnificent effect on the audience's perception of social reality.

After every military coup in Turkey, mass media plays an important role in providing a good representation of journalists in news, TV programmes, and films. In the selected films - The Journalist, Rahmet and Gazap, The Vigilant Journalist - journalists and the mass media are represented as fair, trustworthy, and defenders of the truth. Social obedience can be accepted by people after a military coup with media cultivation perspective.

In The Journalist (Gazeteci, 1980, dir. Yücel Uçanoğlu), the film shows the relationship among a female journalist and her boss and other journalists. There are a few scenes regarding the relationship between the female journalist and her colleague working as a newspaper photographer. The other important element in the film is that the female journalist gathers information by changing her identity. The relationship between the journalist with her news source turns to love in time. The relationship between the female journalist and her colleagues is favourable. First of all, in the beginning of the film, Zeynep and her colleagues are discussing the news regarding the bully. This scene shows that Zeynep's ideas take over and she directs her colleagues' ideas as if she were an opinion leader. Zeynep's relationship with her boss is as good as her relationship with her colleagues. Her boss cares about his colleagues and he is happy with the success of his journalists. The boss is the worried and considerate one who is keens on writing news. In other words, the boss both cares about his news and observes his colleagues carefully. Zeynep starts to write her articles with her real identity after falling in love with Kemal. Kemal learns this and he does not believe that Zeynep loves him and he says that, "If you loved me, you would not write your articles against me". And, Zeynep replies, "I would. I will, too. I am going to write the truth as long as I live". These words show that Zeynep sticks to her profession's ethics as well as her work ethic.

Just as the film The Journalist (Gazeteci, 1980, dir. Yücel Uçanoğlu), in the film Rahmet and Gazap (Rahmet ve Gazap, 1980, dir. Mesut Uçakan), the journalist is represented as an honourable person. The name of the film Rahmet and Gazap is based on Arabic. According to the Turkish Language Association (Türk Dil Kurumu), Rahmet means "forgiving the guilty and having mercy" and Gazap means "anger, furiousness and rage". The film addresses the important points with its name: the religious values and the political values in Turkey. In the film, these two values are represented by the journalist (Abdullah). Abdullah is a religious and hardworking journalist, defending the truth as well as having mercy all the time. However, many evil people are represented as angry and furious in the film. This dilemma shows that journalists are fair, trustworthy, defenders of the truth and they morally outperform other people.

Just like the other two films, the journalist in the film The Vigilant Journalist (Uyanık Gazeteci, 1988, dir. Kartal Tibet) is represented as an honourable, gracious, and news hawk. The journalist is a volunteer and a man of duty all the time. The journalist in the film is brave and risks his life in a war zone. This shows that as white-collar workers, the journalists are trustworthy and they risk their lives for the public's security. If asked to recall the attributes 
of journalism, from the films in this period - these three films as well as the other 14 films based on journalism - not surprisingly, we might recall the scenes, the characters, the lines, the settings, and the actors attempt to grab whatever little information they can get to make quick judgments in interpersonal situations.

\section{Self-Reflexivity of the Films}

The cinema critiques itself by using self-reflexivity. There is a certain tension between self-reflexivity and narrative related to self-reflexivity's association with discourse. Elif Kurtoğlu (2011: 17) states that there is self-reflexivity 'film about films' in Turkish cinema. She highlights that in the films about cinema after the 1960s, there was no critical character until the 1980s and love, revenge, and a fame story were common. Mostly, a young girl coming from a village to a big city for the sake of being an artist. On the other hand, cinema began to be viewed more critically, and self-reflexivity was used consciously with the beginning of the 1980s.

Kurtoğlu (2011: 21) analyses the films made between 1980 and 2006 in four headings as 'films about an actor in a film, 'film which is its own parody', 'films about a cinema lover', and 'films about filmmaking'. It can be stated that 'films about filmmaking' are the most self-reflexive films as they mention cinema itself, and in such films cinema is the most directly referred and critically most self-reflective.

Kurtoğlu (2011) states the high number of "films about film making" in the 1980s is a result of the social and political environment of this period. In some films made between 1980 and 1990, the filmmaker's pressures on the filmmaker's troubles are accompanied by problems such as the pressure of the viewer, the pressure of the period, the freedom and the restraint of creativity.

The most popular scholars regarding film studies in Turkey, Seçil Büker and Semire Ruken Öztürk (2016), highlight that the films made thorough the 1980s, contain the characters of the 12 September military coup, and these films can be called as 'the films of lost men'.

In light of this information above, the three films The Journalist, Rahmet and Gazap, and The Vigilant Journalist present the relationship between media and politics with a selfreflexive approach. Although these three films were made by Turkish mainstream cinema, it can be said that these films characterise the system inside the system. Disinformation, hegemony, and agenda setting are inserted as sub-stories into the scenarios. In addition to this, the audience can compare reality and fiction by taking the references from these three films. The media atmosphere that is presented by these three films is indeed the reflections of the real media atmosphere in 1980s Turkey. In the films The Journalist, Rahmet and Gazap, and The Vigilant Journalist, all the journalists protect and defend the truth, underlining the notion of the freedom of press through the films.

Besides this, at the end of the film The Vigilant Journalist, the audience hears gunshots and then the screen goes dark. This is a reference to ten journalists who were killed in the 
beginning of the 1980s in Turkey. The similar situation occurred in another film, Rahmet and Gazap. Abdullah is not killed in this film, but he is sentenced for defending and writing the truth all the time ${ }^{9}$. Therefore, these two films cannot only problematise reality ontologically, but also they produce their own connections to the transformation and the transformation processes by shifting from one place to another through time and reality.

\section{CONCLUSION}

This study examines themed journalism films produced between the 1980s and the 1990s. It is possible to state that the first reason for journalism films to be observed through the $80 \mathrm{~s}$ and the $90 \mathrm{~s}$. In the political and social history of Turkey, there is a parallel link between these films and the new social and political settlement which was formed by the September 12, military coup in 1980. In this sense, in the early 1980s, journalism became a current issue along with the mass media under the pressure of the military coup in the Turkish Republic.

The selected three films based on journalism discuss the freedom of press and the freedom of expression. The three films all focus on media ethics and freedom of the press. In the films, much of the dialogue shows that the press' assignment is helping justice or that a journalist must always defend press freedom and write the truth. There exists a relationship between the state power and the mass media in every era. Every state power must legitimise its own existence. As the state power tries to legitimise their own legalities, on the other hand, it presents its rules to be supported and observed by the public. Political authorities or state powers use mass media for explaining certain issues to the public and for managing the masses.

The undemocratic change based on the politics in Turkish society was created by the 1960, 1971 and 1980 military coups and mass media played a supporting role for the military power during these periods. The functions of media, such as agenda setting and politicising were tools of legitimation for the military coups and subsequent regimes. Particularly, mass media played an important role for the legitimisation of the 1980 military coup. As can be seen in these films made in the1980s, the press defends the truth and every citizen can express her/his ideas and thoughts freely in Turkey. These three films also show that there is press freedom in Turkey, and as such, the press writes the truth all the time. In these three films, all of the journalists are represented as fair, trustworthy, and defenders of the truth. This shows that the journalists, as white-collar workers, act against corruption in Turkish society. On the other hand, it can be stated with these three films journalism is a difficult profession in Turkey. The state power determines the division of work once more to legitimise its own field in the media. Moreover, it sets up the rule for the journalist to connive. The three films present the relationship between media and politics with their self-reflexivity. Although these three films were made by Turkish mainstream cinema, it can be said that these films characterise the system inside the system. The media atmosphere presented by these three films indeed is the reflections of the real media atmosphere in 1980s Turkey.

\footnotetext{
${ }^{9}$ Similar situations still happens in Turkey. Journalists are sentenced or killed somehow.
} 


\section{References}

>Adaklı, Gülseren (2010) Gazetecilik Etiğini Belirleyen Temel Unsurlar: Mülkiyet ve Kontrol Sorunu (The Main Principles of Media Ethics: Ownership and Control), pp: 61-96 in Çaplı, Bülent and Tuncel, Hakan (ed.) Televizyon Haberciliğinde Etik (Ethics on Television News). Ankara: Fersa Matbaacılık. >Adaklı, Gülseren (2006) Türkiye'de Medya Endüstrisi (Media Industry in Turkey). Ankara:

Ütopya Yayınları.

>Agocuk, Pelin (2015) Türk Sineması'nda melodram: "Seven Ne Yapmaz Filmi Üzerinden Yeşilçam Sineması'nda Melodramın Kodlarının Çözümlenmesi" (Melodrama in Turkish Cinema: "An Analysis of Melodramatic Codes in Yeşilçam Cinema through the Film Seven Ne Yapmaz"). Uluslararası Sosyal Araştırmalar Dergisi (The Journal of International Social Research) 8 (40): 562-576. DOI: 10.17719/ jisr.20154013939.

>Atılgan, Semra (1991) Gazetecilerin Korunması (Protectition of the Journalists). İstanbul: Gazeteciler Cemiyeti Yay.

>Besley, Andrew and Chadwick, Ruth (1992) Ethical Issues in Journalism and the Media. New York: Routledge. DOI: 10.4324/9780203005880.

>Bıçakçı, Ilker (2001) Iletişim Dünyamız -Insan Odaklı Toplumsal Bir Bakış- (Communication World - A Social Approach based on Human). İstanbul: Kapital Medya Hizmetleri.

>Birand, Mehmet Ali (1985) 12 Eylül. Saat: 04.00 (12 September. The Time: 04.00 AM). İstanbul: Karacan Yayınları.

>Büker, Seçil and Öztürk, S. Ruken (2016) Mutlu Son'dan Abluka'ya Türk Sineması (Turkish Cinema from Happy Ending to Abluka), pp. 197-240 in Lale, Özgenel (ed.) Sanat Üzerine Okumalar: 60 Yıla Bakış (The Readings on Art: The Look through 60 years). Ankara: ODTÜ.

>Çalışlar, Oral (2006) 12 Eylül ve Andıçlanan Gazetecilik (12 September and Journalism). İstanbul: Güncel Yayıncılık.

>Chalaby, Jean (1998) Invention of Journalism. New York: St. Martin's Press. DOI: $10.1057 / 9780230376175$.

>Crawford, Nelson A. (1924) The Ethics of Journalism. New York: Alfred A. Knopf.

$>$ Dağtaş, Erdal (2006) Türkiye'de Magazin Basını (Magazine Press in Turkey). Ankara: Ütopya Yayınları. >Demir, Vedat (2006) Medya Etiği (Media Ethics). İstanbul: Beta Yayınları.

>Dicken-Garcia, Hazel (1989) Journalistic Standards in Nineteenth Century America. Madison:

University of Wisconsin Press.

>Dominick, Joseph (2004) The Dynamics of Mass Communication. New York: McGraw-Hill Higher Education.

>Dundelova, Jana and Rozboril, Blahoslav (2012) Social Psychology for Students of Management and Economics. Brno: Faculty of Business and Economics, Mendel University in Brno.

>Dursun, Çiler (2004) Haber, Hakikat ve iktidar iliş̧isi (The Relationship Between News, Truth and the Power) Ankara: Elips Kitap.

>Dyer, Richard (1993) The Matter of Images. New York: Routledge.

>Ehrlich, Matthew (2006a) Facts, Truth, and Bad Journalists in the Movies. Journalism 7 (4): 501-519. DOI: $10.1177 / 1464884906068364$.

>Ehrlich, Matthew (2006b) Shattered Glass, Movies, and the Free Press Myth. Journal of

Communication Inquiry 29 (2): 103-118. DOI: 10.1177/0196859904272741.

>Ehrlich, Matthew (2004) Journalism in the Movies. Chicago: University of Illinois Press.

>Fink, Conrad (1995) Media Ethics. New York: McGraw-Hill Book Co.

>Flint, Leon Nelson (1925) The Conscience of the Newspaper. New York: D. Appleton.

$>$ Foucault, Michel (2015) Iktidarın Gözü (The Eye of the Power). İstanbul: Ayrıntı Yayınları.

$>$ Gerbner, George (1998) Cultivation Analysis: An Overview. Mass Communication \& Society 1 (3-4):

175-194. DOI: 10.1080/15205436.1998.9677855.

>Gerbner, George; Gross, Larry; Morgan, Micheal; Signorielli, Nancy and Shanahan, James (2002)

Growing Up with Television: Cultivation Processes, pp. 43-67 in Bryant, Jennings and Zillmann, Dolf (eds) Media Effects: Advances in Theory and Research. Mahwah, NJ: Lawrence Erlbaum. 
>Gibbons, William Futhey (1926) Newspaper Ethics: A Discussion of Good Practice for Journalists. Ann Arbor, Ml: Edwards Bros.

$>$ Gordon, David and Merrill, John Calhoun (1998) Controversies in Media Ethics. White Plains. New York: Longman Publishers.

$>$ Gürbilek, Nurdan (2009) Vitrinde Yaşamak: 1980'lerin Kültürel I'klimi. (Living in theVitrine: Culturel Atmosphere of the 1980s). İstanbul: Metis Yayıncılık.

>Gürkan, Hasan and Gezmen, Başak (2016) Haber Uygulamaları: Haberin Temel Ilkeleri. (News

Practices: The Main Principles of News). İstanbul: Artes Yayınları.

>Heine, William (1975) Journalism Ethics: A Case Book. London: University of Western Ontario Library. $>$ Henning, Albert F. (1932) Ethics and Practices in Journalism. New York: Long and Smith.

$>$ Hurst, John and White, Sally A. (1994) Ethics and the Australian News Media. Melbourne: Macmillan Education Australia.

>Jensen, Vernon J. (1997) Ethical Issues in the Communication Process. New Jersey: Lawrence Erlbaum Associates. DOI: 10.4324/9780203811184.

>Juusela, Pauli (1991) Journalistic Codes of Ethics in the CSCE Countries. Tampere: University of Tampere.

>Kieran, Matthew (1997) Media Ethics: A Philosophical Approach. Westport, CT: Praeger.

$>$ Kurtoğlu, Elif (2011) Türk Filmlerinde Sinema: 1980 Sonrası Türk Sinemasında Özdüşünümsel/FilmHakkında-Filmler (Cinema in Turkish Films: Self-Reflexivity/Film about Films in Turkish Cinema after 1980s), pp. 9-29 in Kırel, Serpil (ed.) Türk ve Dünya Sineması Üzerine Sentezler (The Notes on Turkish and The World Cinema). İstanbul: Parşömen.

>Lester, Martin Paul and Danre-Ross, Susan (1996) Images That Injure: Pictorial Stereotypes in the Media. Westport, CT: Praeger.

$>$ Lewis, Seth C.; Zamith, Rodrigo and Hermida, Alfred (2013) Content Analysis in an Era of Big Data: A Hybrid Approach to Computational and Manual Methods. Journal of Broadcasting \& Electronic Media 57 (1): 34-52. DOI: 10.1080/08838151.2012.761702.

>Lombard, Matthew; Snyder-Duch, Jennifer and Bracken Campanella, Cherly (2002) Content Analysis in Mass Communication: Assessment and Reporting of Intercoder Reliability. Human Communication Research 28 (4): 587-604. DOI: 10.1111/j.1468-2958.2002.tb00826.x.

$>$ Meyer, Philip (1987) Ethical Journalism. New York: Longman.

$>$ Meyer, Philip (1983) Publishers and Newspaper Ethics. Washington, D.C.: American Society of Newspaper Editors.

$>$ Milan, Alexa (2010) Modern Portrayals of Journalism in Film. The Elon Journal of Undergraduate Research in Communications 1 (1): 45-57.

>Niblock, Sarah (2007) Movie Journalist: Hello Hollywood. British Journalism Review 18 (69): 69-75. DOI: 10.1177/0956474807077795.

$>$ Nordenstreng, Kaarle and Topuz, Hıfzı (1989) Journalist: Status, Rights and Responsibilities. Prague: International Organization of Journalists.

$>$ Nowell-Smith, Geoffrey (1997) Dossier on Melodrama: Minelli and Melodrama. Screen 18 (2): 113118. DOI: 10.1093/screen/18.2.113.

$>$ Olen, Jeffrey (1988) Ethics in Journalism. Old Tappan, NJ: Prentice Hall.

$>$ Özgen, Murat (2004) Türkiye'de Basının Gelişimi ve Sorunları (The Developments and Problems of Media in Turkey). İstanbul: İstanbul Üniversitesi Illetişim Fakültesi Yayınları (Istanbul University Communication Faculty Journal).

$>$ Patterson, Philip and Wilkins, Lee (1998) Media Ethics: Issues and Cases. Dubuque, IA: Wm. C. Brown Publishers.

$>$ Priest, Susanna (1996) Doing Media Research: An Introduction. Thousand Oaks, CA: Sage.

Ramasubramanian, Srividya (2005) A Content Analysis of the Portrayal of India in Films Produced in the West. The Howard Journal of Communication 16 (4): 243-265. DOI: 10.1080/10646170500326533. >Sağnak, Mehmet (2010) Amca Size Gazeteci Diyebilir Miyim? (Uncle, Can I Call You a Journalist?). İstanbul: TB Yayıncılık. 
>Schmuhl, Robert (1984) The Responsibilities of Journalists. Notre Dame: University of Notre Dame Press.

$>$ Stam, Robert (2000) Film Theory an Introduction. Oxford: Blackwell.

$>$ Stroman, Carolyn A. and Jones, Kenneth. E. (1997) The Analysis of Television Content, pp. 271-286 in Asamen, Joy Keiko and Berry, Gordon Berry (eds) Research Paradigms, Television, and Social Behaviours. Los Angeles: Sage Publications. DOI: 10.4135/9781483328201.n9.

$>$ Taş, Oğuzhan (2010) Medya Etiğinin Tarihsel Temelleri ve Gelişimi (Historical Developments of Media Ethics), pp. 153-168 in Çaplı, Bülent and Tuncel, Hakan (eds) Televizyon Haberciliğinde Etik (Ethics in Television News). Ankara: Fersa Matbaacilık.

$>$ Thayer, Lee (1980) Ethics, Morality and the Media. New York: Hastings House.

>Thayer, Lee (1973) Communication: Ethical and Moral Issues. New York: Gordon and Breach. DOI: $10.4324 / 9781315670423$.

>Yetkin, Çetin (1995) Türkiye'de Askeri Darbeler ve Amerika (Coups in Turkey and America). İstanbul: Kilit Yayınları.

>Yılmaz, Yalçın (2015) Türkiye'de Gazetecilik Mesleği (Journalism in Turkey). Ankara: Nobel Yay. 


\section{PRIKAZI NOVINARA U TURSKIM FILMOVIMA: ISTRAŽIVANJE NOVINARSKE ETIKE KROZ FILM}

Hasan Gürkan

SAŽETAK U ovoj se studiji raspravlja o novinarstvu u Turskoj te o tome koliko je dobro ta profesija usklađena s profesionalnim kodeksima novinarstva. U fokusu istraživanja su turski filmovi nastali između 1980. i 1990. U ranim 1980-ima novinarstvo je postalo važna tema jer masovni mediji nisu bili slobodni u Republici Turskoj. Filmovi koji govore o novinarskoj profesiji u tom razdoblju jesu: Gazeteci (Novinar), Rahmet ve Gazap (Rahmet i Gazap) i Uyanık Gazeteci (Probuđeni novinar). U odabranim se filmovima raspravlja o slobodi tiska, o slobodi izražavanja te o medijskoj etici. Te su teme isprepletene melodramatičnim elementom „ljubavi“. Mnogi dijalozi u filmovima pokazuju da je dužnost novina pomagati pravdi ili da novinari trebaju uvijek braniti slobodu tiska i istinito pisati. $U$ tim filmovima naglašena je i društvena poslušnost karakteristična za prošlost Republike Turske.

KLJUČNE RIJEČI

PRIKAZ NOVINARSTVA, ETIKA U FILMOVIMA, FILMOVI U TURSKOJ, 1980-e, MASOVNI MEDIJI

Bilješka o autoru

Hasan Gürkan :: Sveučilište Istanbul Arel, School of Communication, Radio-Television and Cinema, Turska :: gur.hasan@gmail.com 